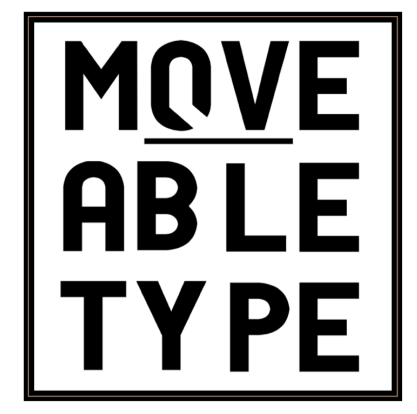

Buried politics: The Ferryman, the Troubles, and the Disappeared

Author[s]: Hana Teraie-Wood

Source: MoveableType, Vol.10, 'Peripheries' (2018)

DOI: $10.14324 / 111.1755-4527.084$

MoveableType is a Graduate, Peer-Reviewed Journal based in the Department of English at UCL.

(C) 2018 Hana Teraie-Wood. This is an Open Access article distributed under the terms of the Creative Commons Attribution License (CC-BY) 4.0https://creativecommons.org/licenses/by/4.0/, which permits unrestricted use, distribution, and reproduction in any medium, provided the original author and source are credited. 
BURIED POLITICS:

\section{THE FERRYMAN, THE TROUBLES, AND THE DISAPPEARED}

HANA TERAIE-WOOD

let assent be divine

As I unveil things profoundly beyond us, Mysteries and truths buried under the earth.

- Seamus Heaney, trans. Aeneid Book VI (2016)

Politics is buried in Jez Butterworth's play, The Ferryman (2017). In an act of political silencing, the Irish Republican Army (IRA) has murdered and buried suspected informer Seamus Carney 'in a bog across the border'. ${ }^{2}$ Pickled in peat, his body serves as a metonym for the power of silence to suspend time, as 'the years roll by, and nothing changes'. ${ }^{3}$ Set in August 1981, at the height of The Troubles in Northern Ireland (196899), The Ferryman is based on the story of Eugene Simons and other members of The Disappeared - a group of sixteen individuals who were murdered and secretly buried by the IRA. ${ }^{4}$ Until the Peace Process in 1995, their deaths were publically unacknowledged and the circumstances and location of their murders undisclosed. The agreement brokered between the British Government and the IRA during the Peace Process has, while helping to locate the bodies, ensured that those responsible for the deaths have not been, and will never be, publicly known. ${ }^{5}$

Butterworth discovered the story while watching Darragh MacIntyre's BBC documentary, The Disappeared (2013) with actress Laura Donnelly, who originally played Caitlin Carney in The Ferryman and whose uncle was Eugene Simons. By 2017, the year

\footnotetext{
${ }^{1}$ Heaney, Seamus, trans. Aeneid Book VI by Virgil (London: Faber, 2016), 354-6, p.16.

${ }^{2}$ Jez Butterworth, The Ferryman (London: Nick Hern Books, 2017), p. 47.

3 Ibid., p.8.

${ }^{4}$ Sandra Peake and Orla Lynch, 'Victims of Irish Republican Paramilitary Violence - The Case of "The Disappeared"', Terrorism and Political Violence, 28.3 (2016), 452-472, 453.

5 Ibid., p.455.
} 
that The Ferryman was written and staged, Brexit had destabilised the borders of Northern Ireland, and Britain had experienced a wave of terrorist attacks. Sam Mendes, director of The Ferryman, noted that 'the politics of the play are so buried, and yet it speaks to us so loudly now'. ${ }^{6}$

In the first academic article on the play, I will argue that The Ferryman is a modern tragedy that uses the context of the Troubles in Northern Ireland - and specifically, the stories of the Disappeared - to explore the pathology of silence, as repressed truths transform into tragic power. The Ferryman's title conjures the image of Charon in the underworld of Virgil's The Aeneid, a literary link which gestures towards the national epic. Seamus Heaney's translation of Aeneid Book VI describes the underworld as a space for unveiling silenced truths buried beneath the earth. The Ferryman adopts this chthonic structure, as personal, familial, and national politics buried within the Carney family and the wider political discourse resurface as memory, confession, and ghosts, driving the characters' tragic actions. The play's setting in the borderland of County Armagh roots rebellion in the soil, as its silenced politics finally rise in rumours, rhetoric, and radicalism.

Sean Carney argues that modern tragedies unearth 'aspects of humanity that have been repressed or disavowed, "buried", so to speak, within the public discourse; in a sense they are public acts of mourning, with an understanding that public mourning is a political act'. ${ }^{7}$ In its final act, The Ferryman enacts justice onstage and creates a dramatic space in which a silenced part of history can be exhumed, debated, and publically mourned, playing out the politics of revenge that remains unchallengeable in the public sphere.

\footnotetext{
${ }^{6} \mathrm{Jez}$ Butterworth and Sam Mendes, 'Jez Butterworth and Sam Mendes on The Ferryman' Front Row, BBC Radio 4, 22 June 2017 <https://www.bbc.co.uk/programmes/b08tvjkc> [accessed 10 January 2018]. ${ }^{7}$ Sean Carney, The Politics and Poetics of Contemporary English Tragedy (Toronto: University of Toronto Press, 2013), p.16.
} 


\section{Borderland}

Land speaks history in The Ferryman. Set in the border county of Armagh, Butterworth positions his play at the point of dispute of the Troubles, along what many Republicans viewed as the "unnatural' ${ }^{8}$ imperial fissure between Northern Ireland and the Republic. Arthur Miller stated that modern tragedies stage 'the cramping of our lives', and the cramped political and economic livelihoods of Northern Irish Catholics are sown into the play's soil. Plantation by the English in the 1600s pushed Northern Irish Catholics into marginalised plots of the least fertile land, creating entrenched inequalities which culminated in what R.F. Foster calls the 'agrarian secret-society tradition', fuelling the conflicts of the Land Wars, the Easter Rising, and, ultimately, the Troubles. ${ }^{10}$ This legacy is lived upon by the farming Catholic Carneys, as the land and its politics are inherited through the generations; father of the household, Quinn Carney, proudly proclaims this lineage at the harvest table: 'This was Big Jack's farm. And his father's father before him'. ${ }^{11}$ The exact location of the Carney's farmhouse is undisclosed until well into Act Two, leaving the audience to guess location from accents, hints in dialogue, and set paraphernalia, such as the 'Celtic $\mathrm{FC}^{12}$ scarf draped in the recesses onstage. This ambiguity conveys how the underlying political tension of the land is uncomfortably suppressed within the Carney's domestic lives.

\footnotetext{
${ }^{8}$ Christopher Hitchens quoted in Henry Patterson, Ireland's Violent Frontier: The Border and Anglo-Irish Relations During the Troubles (Basingstoke: Palgrave Macmillan, 2013), p.2.

${ }_{9}$ Arthur Miller, 'Tragedy and the Common Man', Jewish Quarterly, 62.4 (2015), 62-63, 63.

${ }^{10}$ R.F. Foster, 'Ascendancy and Union' in The Oxford History of Ireland ed. by R.F. Foster, (Oxford: Oxford University Press, 2001) 134-173, 170; James Loughlin, The Ulster Question since 1945, 2nd ed. (Basingstoke: Palgrave Macmillan, 2004), p.49.

11 Butterworth, Ferryman, p.68.

12 Ibid., p.11.
} 
The Prologue initially confines the Troubles to the play's borders. Its setting in 'An alley in Bogside, Derry. Back of a building. The wall is painted with Republican graffiti' introduces the secret underworld of the IRA operating in backstreet urban spaces. This marginality is conveyed by the cramped set, with the alley wall just a few metres from stage front. The Prologue introduces the play's anti-Gods - Malone, Magennis, and Muldoon - who, as local IRA members attempt to divine, like Juno in the opening lines of The Aeneid ${ }^{14}$, the fates of the characters onstage. Their responsibility for Seamus's death is inferred, as is their tight control over local services and the media. Despite their access to 'police photograph[s]' of Seamus's body, we see that Magennis, relaxed against the wall, is 'reading a paper' with no headlines covering Seamus's murder. ${ }^{15}$ In my interview with Sandra Peake, CEO of WAVE - the grassroots organisation chiefly responsible for supporting the families of the Disappeared - she comments that 'most times there was nothing in the papers ${ }^{16}$ about the disappearances, as the stories were buried from public discourse for fear of shame and violent repercussions. Muldoon's blackmailing of Father Horrigan in the Prologue dramatises this social control, but it also departs from acknowledged fact: priests are not known to have been blackmailed in this way during the Troubles. ${ }^{17}$ Butterworth arguably manipulates history at the risk of caricaturing the IRA, and his positioning of the Prologue in famous Derry - 'the capital city of injustice' in Republicans' eyes and the site of the Battle of the Bogside (1969) and Bloody Sunday (1972) - may pander to recognisable tropes of the Troubles for its non-(Northern)Irish audience. $^{18}$

\footnotetext{
13 Ibid., p.6.

14 Virgil, The Aeneid, trans. by Robert Fagles. (London: Penguin, 2010) 1.1:90.

${ }^{15}$ Butterworth, Ferryman, p.8, 6.

${ }^{16}$ Sandra Peake, Personal Interview, 18 January 2018.

${ }_{17}$ Darragh MacIntyre, Personal Interview, 8 January 2018.

${ }^{18}$ Ed Moloney, A Secret History of the IRA (London: Penguin, 2002), p. 63; Marie-Therese Fay, Mike

Morrissey, and Marie Smyth, Northern Ireland's Troubles: The Human Costs (London: Pluto Press, 1999), p.147.
} 
The tension between Quinn Carney's escape from and entrapment by violent national politics is suggested by the sound bridge of " Street Fighting Man" by The Rolling Stones, loud' which ferries the audience in 'Blackout' between Derry and Act One. ${ }^{19}$ As lights rise on the farmhouse, Quinn dances wildly, inebriated, to Jagger screeching, 'Everywhere I hear the sound of marching, charging feet, boy. ${ }^{20}$ The song, released in 1968, was a rallying cry of the civil rights movement which sparked the Troubles. ${ }^{21}$ Quinn's moment of acting out captures his fight against, and partaking in, a national political discourse. Etymologically, Quinn is the "Anglicized form of Ó Cuinn "descendant of Conn", meaning 'chief, leader'; Carney is the Anglicised form of Kearney: 'warlike', 'victorious', 'foot soldier'. ${ }^{22}$ Quinn's military and colonised history is inscribed into his character: he is a streetfighter in exile. The play's setting in a 'farmbouse kitchen, in rural Northern Ireland, harvest time ${ }^{23}$ deliberately disguises The Ferryman as a domestic drama, as the kitchen sink takes centre stage for the three acts. The vaulted, cavernous, high ceilinged kitchen, filled with real familial paraphernalia from the actors' homes, ${ }^{24}$ creates an appearance of abundance and space, crowding out the absence of Seamus Carney and the bloodied history of the soil beneath. With the majority of The Ferryman staged in rurality beyond urban warfare, dramatic tension is created between the Prologue and the Carney home: as

\footnotetext{
${ }^{19}$ Butterworth, Ferryman, p.10.

20 'Street Fighting Man' in Beggars Banquet (London: Decca, 1968).

21 ‘100 Greatest Rolling Stone Songs’ Rolling Stone, (15 October 2013)

< https://www.rollingstone.com/music/lists/100-greatest-rolling-stones-songs-20131015> [accessed 10 January 2018].

22 Patrick Hanks, Kate Hardcastle, and Flavia Hodges, 'Quinn' in A Dictionary of First Names, 2nd ed. (Oxford: Oxford University Press, 2006)

http:/ /www.oxfordreference.com/view/10.1093/acref/9780198610601.001.0001/acref-9780198610601-e2635? rskey $=$ FyW7uB\&result $=1>[$ accessed10 January 2018]; Richard A. Coates, Patrick Hanks, and Peter McClure, 'Kearney' in The Oxford Dictionary of Family Names in Britain and Ireland (Oxford: Oxford University Press, 2016) < http://www.oxfordreference.com/view/10.1093/acref/9780199677764.001.0001/acref9780199677764-e-21983\#> [accessed 10 January 2018].

23 Butterworth, Ferryman, p.11.

${ }^{24} \mathrm{Jez}$ Butterworth and Sam Mendes.
} 
Butterworth comments on his earlier plays, 'It's what's left off that ignites what's on'. ${ }^{25}$ The realities of the Troubles grow and fester in the audience's minds, as stories of the conflict accumulate throughout the play and slowly exert pressure on the farmhouse's familial borders.

The harvest festivities, which are the play's centre piece, are another reassertion of borders. According to Naomi Conn Liebler, festive tragedies, from 'festum ("feast")' display 'the celebration of a community's survival', a 'ritual to protect and reaffirm' values. $^{26}$ The harvest is an act of defiant bounty at the time of the hunger strikes in August $1981 .^{27}$ Yet Tom Kettle's reading of Sir Walter Raleigh's poem, 'The Silent Lover' at the harvest table inadvertently invokes the spectre of the Potato Famine, for, according to his biographer, Raleigh was remembered for 'some of the worst horrors' in Ireland under Elizabeth I and for bringing the first potatoes to Ireland in $1588 .^{28}$ Further, the legacy of Plantation, felt by Catholics complaining of poor land well into the $1980 \mathrm{~s},{ }^{29}$ is aired by Aunt Pat:

AUNT PAT. The 1976 Agricultural Act decreed weather in South Armagh too damp to grow crop for human consumption. Since when Quinn's wheat gets packed up and shipped off to Poland for animal feed.

MULDOON. And what types of animal are they?

AUNT PAT. Pigs.

MULDOON. Pigs, eh? Polish pigs? ? $^{30}$

Aunt Pat ventriloquises the unwelcome bureaucracy of the British Government, a twentieth-century manifestation of British rule against Catholic Northern Irish livelihoods. As the audience sees the Carneys enjoying the land's harvest, the crops'

${ }^{25}$ Jez Butterworth quoted in David Ian Rabey, The Theatre and Films of Jez Butterworth (London: Bloomsbury, 2015), p.10.

${ }^{26}$ Naomi Conn Liebler, Shakespeare's Festive Tragedy: The Ritual Foundations of Genre (London: Routledge, 1995), p.12, 8.

${ }^{27}$ Paul Bew and Gordon Gillespie, Northern Ireland: A Chronology of the Troubles 1968-1999 (Dublin: Gill \& Macmillan, 1999), p.154.

${ }^{28}$ Raleigh Trevelyan, Sir Walter Raleigh (London: Penguin, 2002), p.32; K.H. Connell, 'The Potato in Ireland' in Nationalism and Popular Protest in Ireland, ed. by C.H.E. Philpin (Cambridge: Cambridge University Press, 1987), pp.110-125, p.110.

${ }^{29}$ Patterson, p.4.

${ }^{30}$ Butterworth, Ferryman, p.77. 
unworthiness of 'human consumption' speaks hypocrisy. Law relegates the Carneys to animals, like 'Polish pigs', which hints to changes enacted by Northern Ireland's entry into the European Economic Community in $1973 .{ }^{31}$ The laughter elicited in the London audiences is recycled to unsettling effect, as the 'Polish pigs' draw an uncomfortable link to the anti-Polish undertones of the contemporary Brexit debate which continues to fuel discussions today. ${ }^{32}$ Northern Ireland's vote to stay in the EU by $56 \%{ }^{33}$ questions whether England has again exercised authority to manipulate Northern Irish borders and jeopardise the livelihoods of families like the Carneys against their will.

The land's colonial legacy is resurrected in Tom Kettle. Prominent poet and Irish Republican Thomas Kettle (1880-1916) was famously a 'gifted speaker with an incisive mind and devastating wit. ${ }^{34} \mathrm{He}$ is recast with irony as the play's sole Englishman, who struggles with speech and is 'not the full bucket'. ${ }^{35}$ His similarities to John Steinbeck's Lennie Small in Of Mice and Men - with their shared love of rabbits and ability to stack bales $^{36}$ - inscribes in Kettle a sincere humanity and his role as melting pot for societal violence:

TOM KETTLE. Would you like an apple, Mr Muldoon. I grew it in my garden. It's a Royal Gala.

MULDOON. Sure, that doesn't sound like an Armagh apple.

TOM KETTLE. I sent off for the seeds. In 1953, to celebrate the Queen's Coronation. ${ }^{37}$

\footnotetext{
${ }^{31}$ D.S. Johnson and Liam Kennedy, 'The Two Economies in Ireland in the Twentieth Century' in $A$ New History of Ireland VII: Ireland, 1921-84, ed. by J.R. Hill (Oxford: Oxford University Press, 2003), pp.452-472, p.472.

${ }^{32}$ See Stewart Paterson, 'Married Polish couple want YOU to fund their Brexit! Family plead for $£, 10,000$ on fundraising site to get them back to Krakow... after EU vote left them 'stressed and insecure' in UK.' Daily Mail Online, (12 September 2017) < http://www.dailymail.co.uk/news/article-4875672/Married-Polishcouple-want-fund-Brexit.html> [accessed 18 January 2018].

${ }^{33}$ Jonathan Tonge, 'The Impact of Withdrawal from the European Union upon Northern Ireland', The Political Quarterly, 87: 3 (2016), 339-342, 339.

${ }^{34}$ D.J. Hickey and J.E. Doherty, 'Kettle, Thomas M.' in A Dictionary of Irish History Since 1800 (Dublin: Gill and MacMillan, 1980), p.279.

35 Butterworth, Ferryman, p.86.

${ }^{36}$ See John Steinbeck, Of Mice and Men (New York: Random House, 1974), p. 115, 42; Butterworth, Ferryman, p.26, 30.

37 Butterworth, Ferryman, 76.
} 
In a tense tête-à-tête with the head of the local IRA, Kettle's use of the possessive 'my garden' unconsciously and uncomfortably mimics the ownership exercised by English landowners from the 1600 s and onwards. As Kettle innocently repeats the cycle of plantation by Royalists in Armagh, a county already known for its apples, ${ }^{38}$ Butterworth ironises England's historically flippant view of Ireland as her backyard. The imported 'seeds' which celebrate Queen Elizabeth II's coronation pun on Queen Elizabeth I's brutal plantation of Ulster. Muldoon's response - 'What is an Englishman doing all the way out here now? ${ }^{39}$ - encompasses the entire Republican cause. Yet Kettle's unawareness of subtext highlights the refusal of other characters, imbued with sectarianism, to accept his naïveté. Free of embitterment, Kettle is the most empathetic character towards Caitlin: he tells her that 'I understand" ${ }^{40}$ six times in the wake of Seamus's death. Yet his final, shocking act of killing Oisin with the same method that he applied to the harvest goose - 'I wrung his neck' - mimics the barbarism of the IRA, who will disappear humans because, in the words of ex-IRA member Brendan Hughes, 'the order was given for them to be put down'. ${ }^{41}$ Kettle's mental disorder frees him of murderous intent and isolates the act from the actor, redistributing guilt among the characters onstage - and, possibly, with the English audience. This violence registers the Carneys' resistance to English colonisation as fruitless, as the land's historical inequalities are revived. History is resurrected to have the final say, as its buried politics come alive to kill.

\footnotetext{
${ }^{38}$ Conor Macauley, 'County Armagh apple growers: Harvest worth $£ 20 \mathrm{~m}$ a year' BBC News, BBC (29 September 2015) <https://www.bbc.co.uk/news/uk-northern-ireland-34381677> [accessed 18 February 2018].

${ }^{39}$ Butterworth, Ferryman, p.76.

${ }^{40}$ Ibid., p.88.

${ }^{41}$ Ibid., p.127; Brendan Hughes interviewed in The Disappeared (television programme), BBC4, 5 November 2013, < https://learningonscreen.ac.uk/ondemand/index.php/prog/05F71CCC> [accessed 2 July 2018].
} 


\section{Silence}

Politics is buried in the silences of The Ferryman. A loud, vibrant play, its silences - fortynine are written into its stage directions - are particularly pronounced. They reflect how, 'throughout The Troubles [...] silence and related notions of loyalty permeated all levels of society'. ${ }^{42}$ The Disappeared were, and still are, a paradigm of this silence, for, as Darragh MacIntyre simply puts it, 'by definition people didn't know what happened to them'. ${ }^{43}$ This absence of information finds its most lucid dramatic outlet in Seamus's teenage son, Oisin Carney, whose tragic trajectory sees his anger, stemming from the absence of his father, Seamus, transform into radical action. His tragic attempt to kill Tom Kettle dramatises the damage that silence creates within the family. Laura Donnelly noted that her mother rarely spoke of Eugene's disappearance:

We just got a sense that it wasn't something we talked about. I think, either consciously or not, my parents made a decision to really neutralise the politics in our family. ${ }^{44}$

This omission of the political, which is mirrored in the onstage relationship between Oisin and Donnelly's role as his mother, Caitlin, pushes Oisin into eavesdropping, as he seeks facts from elsewhere. The stage, on which 'there is no visible door ${ }^{45}$ allows Oisin to eerily appear in silence and overhear characters without drawing their attention. As Jean Howard observes, silent mimes and movements onstage throw into sharp relief 'the role language plays in the "making sense" process', ${ }^{46}$ and Oisin's uncanny, puppet-like appearances convey silence's dehumanising power. Instead, damaging rumours spread by the IRA about Seamus, as heard by Oisin on the street - 'my ears aren't innocent. Sure,

\footnotetext{
42 Peake and Lynch, p.452.

${ }^{43}$ Darragh MacIntyre, Personal Interview, 8 January 2018.

${ }^{44}$ Laura Donnelly, 'The Ferryman's Laura Donnelly on how her uncle's murder inspired the IRA drama' The Guardian, (8 August 2017) < https://www.theguardian.com/stage/2017/aug/08/laura-donnelly-theferryman-jez-butterworth-paddy-considine $>$ [accessed 21 December 2017].

45 Sam Mendes, 'In Conversation with Sam Mendes' Programme for Jez Butterworth's The Ferryman at the Gielgud Theatre, (London: Dewynters, 2017), pp.35-36, p.36.

${ }^{46}$ Jean E. Howard, Shakespeare's Art of Orchestration: Stage Technique and Audience Response (Illinois: University of Illinois Press, 1984), p.90.
} 
I've heard ten times worse at school ${ }^{47}$ - fill his void with misinformation and misguide him towards radicalism.

According to Adrian May, myth unfolds stories to 'show us what we are inclined to ignore', charting 'what we tend to forget'. ${ }^{48}$ Ironically, the mythical tales told by the dementia suffering Aunt Maggie Faraway fill the silences kept within the family, as her myths make sense of the past and portend the future. Onstage for most of the play, she is the repository of secrets: 'AUNT MAGGIE watches everything'. ${ }^{49}$ She breaks the silence surrounding Seamus's disappearance, telling the children that 'Seamus is in the ground, girls. Seamus is in the ground ${ }^{50}$ Her singing of 'The Stolen Child' by W.B. Yeats ${ }^{51}$, first published in his collection, The Wanderings of Oisin and Other Poems (1889), foresees the fate of Oisin, whose wandering to Kettle's outhouse leads to his death. As Aunt Maggie sings 'The Stolen Child', silence descends onstage, as a slippage occurs between the characters' surprise of Aunt Maggie speaking, and an uncanny sense that she is foreseeing the play's tragic denouement. Yeats's poem, which was one of 'the first major works of the [Irish literary] revival based on Gaelic mythology', shows how myth, recycled for political purposes, appears to hold an 'unchanging wisdom'. ${ }^{52}$ However, Sean O'Hagan - a critic who vocally dissented from The Ferryman's overwhelmingly positive reviews - argues that Butterworth here performs dramatic Irishness, by delivering a heavy dose of Irish mythmaking. ${ }^{53}$ Aunt Maggie's position on stage left, opposite the staunchly vocal Republican

\footnotetext{
${ }^{47}$ Butterworth, Ferryman, p.24.

48 Adrian May quoted in Rabey, p.24.

${ }^{49}$ Butterworth, Ferryman, p.72.

50 Ibid., p.60.

51 Ibid., p.33.

52 Vivian Mercier, 'Literature in English, 1891-1921' in A New History of Ireland VI: Ireland under the Union 1870-1921, ed. by W.E. Vaughan (Oxford: Oxford University Press, 2012), pp.357-384, p.365, 364.

53 Sean O'Hagan, 'Critics loved The Ferryman. But I'm from Northern Ireland, and it doesn't ring true' The Guardian, (16 July 2017) < https://www.theguardian.com/commentisfree/2017/jul/16/jez-butterworth-theferryman-irish-stereotypes-sam-mendes $>$ [accessed 29 June 2018].
} 
Aunt Pat on stage right, uncomfortably paints two poles of Irish heritage - the mythic and the political - with, arguably, little nuance in between.

The Corcoran and Carney boys' debate over Seamus's guilt demonstrates how extreme narratives propagate when difficult questions are silenced:

JJ. So they were just beating on a Catholic boy?

DIARMAID. They was punishing him.

JJ. What for?

SHANE. Because he fucked up.

MICHAEL. Like Uncle Seamus. ${ }^{54}$

As extended family members from Derry, Diarmaid and Shane Corcoran represent the wider response to Seamus's disappearance. Here, it is only after the liberation of a night of 'drinking whiskey' ${ }^{55}$ with the adults offstage, that the shame of Seamus's death is discussed. As Eunan O'Halpin points out, 'The term 'informer' [...] has a particular resonance in Irish nationalist memory [...] blamed for successive failures to throw off the British yoke', with the practice of disappearing informers reaching back to the War of Independence. ${ }^{56}$ This taboo is exhumed by the IRA, as the 'boy' who 'fucked up' 'was gagged'57: a clear punishment for speaking out. Butterworth notes that:

You can look at the Corcoran boys and look at those pictures of the four people who were radicalized in Barcelona. The process of radicalization is going on in that late-night scene. ${ }^{58}$

The Corcorans, in black leather boots and leather jackets, echo the dress of Muldoon's men, signalling their influence. In opposition, the Carneys' white trainers remind the

\footnotetext{
${ }^{54}$ Butterworth, Ferryman, p.98.

55 Ibid., p. 90 .

${ }^{56}$ Eunan O’Halpin, 'Problematic Killing in the Irish War of Independence: the Killing of Spies and Informers.' in Death and Dying in Ireland, Britain and Europe: Historical Perspectives, ed. by James Kelly and Mary Ann Lyons (Sallins: Irish Academic Press, 2013), pp.317-348, p.320, 321.

${ }^{57}$ Butterworth, Ferryman, p.97.

58 Jez Butterworth, 'The Ferryman: Jez Butterworth on the Legacy of Hate', The Atlantic (5 September 2017). < https://www.theatlantic.com/entertainment/archive/2017/09/the-ferryman-jez-butterworth-on-thelegacy-of-hate/537984/> [accessed 10 February 2018].
} 
audience of the 'Gola trainers' that Seamus was found buried in - the same shoes which Brian McKinney was found wearing in his grave after his disappearance in 1978 aged 22, as was revealed in The Disappeared (see Figure 1). ${ }^{59}$ The white Gola trainers, fashionable among young men in the 1970s, function as a timestamp, freezing Seamus in his youth, while communicating in the white-black opposition a less radical politics. This subtle connection back to Seamus's body in the Prologue demonstrates how Butterworth creates what Noel Grieg calls 'depth charges', ${ }^{60}$ as motifs repeat and resurface within the play to build meaning. The trainers gather an emotional charge, as they force the audience to consider whether Seamus was any different from the Carney boys onstage, and if he had indeed 'fucked up' at all. Speaking out becomes a dangerous act in The Ferryman, as silence acts as social control to manipulate young minds filled with radical voices.

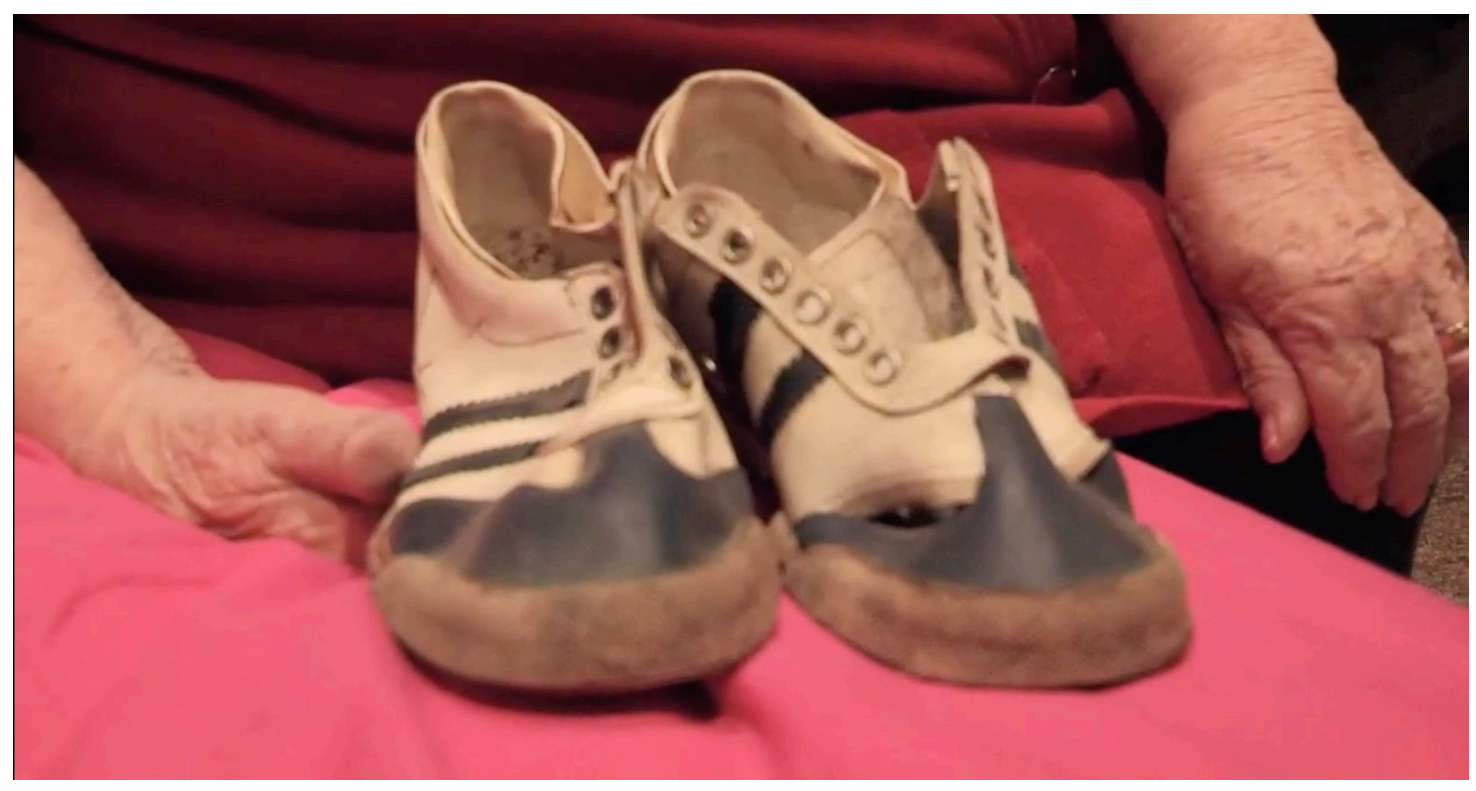

Figure 1: Still from The Disappeared: Brian McKinney's Gola trainers.

The evasion of political rhetoric in the Carney family is disrupted by Aunt Pat, as she resurrects the spectres of the hunger strikers:

\footnotetext{
${ }^{59}$ Butterworth, Ferryman, p.7; The Disappeared (television programme).

${ }^{60}$ Noel Grieg quoted in Rabey, p.21.
} 
Suddenly AUNT PAT switches off the tape player [...]

Silence. AUNT PAT turns. Silence.

AUNT PAT. Michael Devine has starved himself to death.

Silence.

Michael Devine. Thomas McElwee, Kieran Doherty. Kevin Lynch. Martin Hurson, Joe McDonnell. Patsy O’Hara. Raymond McCreesh. Francies Hughes. Bobby Sands.

Silence.

QUINN. To the hunger strikers. ${ }^{61}$

As Jean Howard argues, silences are a 'way of calling attention to a potentially important stage moment', ${ }^{62}$ and the silence created by Aunt Pat as she switches off the music signals a turning point in the play. In the midst of the festivities, Aunt Pat revives the suppressed conversation around contemporary nationalist politics, as the bearded, emaciated, Christlike forms of the hunger-strikers haunt the harvest table, their images pulling on a lineage of 'self-sacrificial deaths' in Irish nationalism. ${ }^{63}$ This fearless speaking out garners Aunt Pat her position as Oisin's surrogate matriarchal figure. At the end of Act One, as Oisin stares at the Christ-like hanging carcass of the harvest goose, ${ }^{64}$ it is clear that he has absorbed the rhetoric of martyrdom. It is pertinent that Oisin steals Aunt Pat's pistol to kill Tom Kettle: inherited from Aunt Pat's brother who died in the Easter Rising, the pistol gathers its own depth charge. Its changing of hands down the generations shows how, in the wake of silence, the radical politics buried within the Carney family resurfaces and repeats.

\footnotetext{
${ }^{61}$ Butterworth, Ferryman, p.73-74.

${ }^{62}$ Howard, p.96.

${ }^{63}$ John Wolffe, 'The Mutations of Martyrdom in Britain and Ireland, c. 1850-2005' in Death and Dying in Ireland, Britain and Europe: Historical Perspectives, ed. by James Kelly and Mary Ann Lyons (Sallins: Irish Academic Press, 2013), pp. 349-368, p.363.

${ }^{64}$ Butterworth, Ferryman, p.53.
} 


\section{Justice}

The Ferryman exposes how Republican politics was buried during the Troubles from British political discourse. As Aunt Pat tunes in to the BBC World Service on her radio, Thatcher's disembodied voice rings onstage:

There can be no question of political status for someone who is serving a sentence for crime. Crime is crime is crime. It is not political. ${ }^{65}$

Butterworth condenses time to abide the Aristotelian unities of time and place, as he places this speech, initially broadcast in April 1981, ${ }^{66}$ at the centre of harvest preparations. The speech demonstrates Thatcher's refusal to acknowledge the hunger-strikers' political status, which, in riposte, led to Bobby Sands' famous phrase, 'I am hungry only for justice ${ }^{97}$ Her disembodied voice makes visible the 'formless and bureaucratic face of state power ${ }^{68}$ while highlighting the distance from which it extends. This melding of politics and criminality sees history recycle, repeating how British official death tolls from the Easter Rising 'make no distinction between insurgents and civilians' ${ }^{69}$ Yet, Quinn's act of switching the radio off signals how the contentious political discourse is also censored at home.

Act Three uncovers how justice for the families of the Disappeared was denied. Due to terms agreed to in secret by the British Government and IRA, the families had 'to sacrifice the option of a criminal justice resolution' in exchange for information on the location of the burial sites. ${ }^{70}$ But most families knew who was involved in their loved one’s disappearance:

\footnotetext{
65 Ibid., p.36.

${ }^{66}$ Margaret Thatcher, 'Press Conference ending visit to Saudi Arabia (IRA hunger strikes)', Margaret Thatcher Foundation, (21 April 1981) <https://www.margaretthatcher.org/document/104501> [accessed 1 February 2018].

${ }^{67}$ Butterworth, Ferryman, p.92.

${ }^{68}$ Rabey, p.13.

${ }^{69}$ F.S Lyons, 'The Rising and After' in A New History of Ireland VI: Ireland under the Union 1870-1921, ed. by W.E. Vaughan (Oxford: Oxford University Press, 2012), pp. 207-223, p.217.

70 Peake and Lynch, p.455.
} 
I believe I know the people who done it and I'll always know them. And even the day of my father's funeral I had to thank those people. I felt it was something I had to do. I had to get up and thank whoever gave us that information. ${ }^{71}$

Caitlin's wooden thanks to Muldoon -'I thank you for the kindness you've shown me and my son'- dramatises how, in the face of Seamus's killer, justice was sacrificed in exchange to 'bury Seamus in peace'. ${ }^{72}$ The terms of this exchange show again the strapping of silence:

QUINN. I accept that neither you, nor anyone you know, was involved in the disappearance of Seamus Carney. (Beat.) That no one will speak a word on the subject. No one will talk to the press. No one will breathe a word to anyone. It's in the past and it will stay in the past. ${ }^{73}$

As Quinn states these facts face-to-face with Muldoon, the hypocrisy of this agreement (which the audience feels through the 'Beat') is made dramatically clear. The gagging of the families by the IRA, who also negotiated that 'no post mortem or other forensic examination would be undertaken' and 'that the funerals had to be held in private ${ }^{774}$, is laid bare. Muldoon's use of Quinn's children to secure his silence - 'For Honor. Mercy. $[\ldots]$ Bobby $^{75}$ - takes on a sinister double meaning, as their names play on the traits asked of the Republican cause and bring into terrifying proximity the memory of Bobby Sands and Quinn's youngest baby, also called Bobby, who is seen live onstage.

Justice - in some part - is delivered onstage. As Jean-Paul Sartre claimed, 'The law is theater', 'the stage is the courtroom in which the case is tried'. ${ }^{76}$ In line with the Greek tradition, Butterworth creates a dramatic space where the publically unchallengeable is tried, as judgement on the IRA is performed. Donnelly, in her role as Caitlin, is given an audience with Muldoon to assert that the rumours spread by the IRA 'didn't work, see. I

\footnotetext{
${ }^{71}$ Anna McShane interviewed in The Disappeared (television programme).

${ }^{72}$ Butterworth, Ferryman, p.125, 123.

73 Ibid., p.123.

${ }^{74}$ Peake and Lynch, p.455.

75 Butterworth, Ferryman, p.124.

${ }^{76}$ Jean-Paul Sartre quoted in Kerrigan, p.28.
} 
knew. You never got me, Mr Muldoon. You never got me. ${ }^{77}$ Donnelly described playing Caitlin as 'cathartic', and her well-publicised familial link draws on the audiences' pathos, as her confrontation poignant slips between reality and stage.

The isolation of the families of the Disappeared from the $\operatorname{church}^{79}$ is given an imagined judgement as Uncle Pat reads from The Aeneid:

Enter QUINN from upstairs, unseen. He is dressed differently.

"Son of Anchises, true child of the gods, all this crowd, you see, they are the unburied. The ferryman is Charon. He may not carry them from the fearful shore on the harsh waters before their bones are at rest in the earth. They roam for a thousand years lost on these shores, their souls abandoned. Only then are they admitted, and revisit the pools they long for." Silence.

QUINN. Who's there?

UNCLE PAT. Fear not, Quinn. It's that old fool Pat, and the Father... ${ }^{80}$

Father Horrigan, who betrayed the Carneys by colluding with the IRA is judged by Quinn from his elevation 'upstairs'. Quinn's shout of 'Who's there?' continues the play's trope of overhearing and mimics the first line of Hamlet, ${ }^{81}$ invoking in the 'Silence' the presence of a ghostly betrayal. This quoted passage from The Aeneid, spoken by Sibyl - the vates and guide to the underworld - poses The Ferryman's central question of who holds power to end lives and bury souls in peace or without. As he brings their ghosts in tow, Horrigan is faced with an image of the unburied who he abandoned, having failed to deliver burial rites to ferry their souls from earth to heaven. However, Quinn asserts his own agency, as his change of clothes suggests a switch to battle dress before his final act of taking revenge, mirroring Aeneas's assent from the underworld in Book VI to war thereafter.

\footnotetext{
${ }^{77}$ Butterworth, Ferryman, p.84.

${ }^{78}$ Laura Donnelly, 'Actress Laura Donnelly on how uncle's IRA murder inspired hit West End play', The Irish News, (11 September 2017) < https://www.irishnews.com/arts/2017/09/11/news/actress-lauradonnelly-on-how-uncle-s-ira-murder-inspired-hit-west-end-play-1130900/ $>$ [accessed 1 February 2018].

${ }^{79}$ As stated by Eugene Simons's father, Walter Simons, 'There was no one you could talk to, not in the church or anywhere else.' Quoted in WAVE, The Disappeared of Northern Ireland's 'Troubles' (Belfast: WAVE Trauma Centre, 2012), p.75.

${ }^{80}$ Butterworth, Ferryman, p.114.

${ }^{81}$ William Shakespeare, Hamlet, ed. G.R. Hibbard. (Oxford: Oxford University Press, 1998), 1.1:1.
} 
The Ferryman reclaims the space, left vacant by official discourse, to judge Quinn's act of revenge. Act Three resembles a revenge tragedy, as it stages what John Kerrigan calls an 'ethical deadlock: moments of trial within and beyond character in which rhetoric is, in the liveliest sense, an agent of action, ${ }^{82}$ Muldoon reminds Quinn of his old values:

you'd watch that baby burn in the fire, if it meant a free Ireland. And I thought, "that is what it takes. That is the cost of freedom."

Sean O'Hagan critiques this line as caricaturing Muldoon beyond redemption. ${ }^{84}$ This analysis overlooks the moment's dramatic potential to humanise, as it verbalises the extremes of ethical deadlock between political freedom and home-life. Initially banned by the British Government for humanising terrorists, the BBC documentary Real Lives: At the Edge of the Union (1985) filmed Martin McGuinness feeding his children at home whilst also undertaking his duties as IRA Chief of Staff (see Figure 2) ${ }^{85}$ Butterworth revives this mix of domesticity and violence in Quinn, which ultimately culminates in 'blood spurts all over the wall of family pictures. ${ }^{86}$ Quinn's lack of formal justice avenues demonstrates how, as Adrian Poole conjectures, there is in tragedy 'no logical escape from the nightmare'. ${ }^{87}$ Quinn's ethical space is cramped by sectarianism, as inevitable death becomes the only risk-free escape from injustice.

Quinn's quip that the past 'will stay in the past' is misleading. The past avenges in The Ferryman, as the play's buried injustices surface as ghosts. Each act ends with the building of an unsettling noise, revealed in the final scene as 'the Banshees scream' ${ }^{88}$ According to Yeats, banshees wail before a death, and 'When more than one banshee is

\footnotetext{
${ }^{82}$ Kerrigan, p.29.

${ }^{83}$ Butterworth, Ferryman, p.82.

84 O'Hagan.

85 'Real Lives 1985' History of the BBC, BBC

< http://www.bbc.co.uk/historyofthebbc/research/culture/bbc-and-gov/real-lives $>$ [accessed 1 February 2018].

${ }^{86}$ Butterworth, Ferryman, p.128.

87 Adrian Poole, Tragedy: A Very Short Introduction (Oxford: Oxford University Press, 2005), p.36.

${ }^{88}$ Butterworth, Ferryman, p.129.
} 
present, and they wail and sing in chorus, it is for the death of some holy or great one'. ${ }^{89}$ The chorus of banshees thus grant the Carneys mythic status, like the giants and Jonny Rooster Byron at the end of Jerusalem. ${ }^{90}$ Ghosts in Irish folklore live in a state of intermediary between this life and the next. They are held there by some earthly longing or affection, or some duty unfulfilled, or anger against the living. ${ }^{91}$ The banshees, or ghosts, return onstage in an act of retributive justice. It is a repeat of family history, recalling Aunt Pat's return from the Easter Rising with 'Banshees. Ten thousand. ${ }^{92}$ The banshees' cry could also be the sound of the combine harvesters, or of Muldoon's men coming to arms, creating ambiguity akin to Jerusalem, as the sound of giants melds with the trucks driving to flatten Byron's home. ${ }^{93}$ The ghosts, therefore, may represent liberation or a final enclosure. Uncle Pat's quotation from The Aeneid states that ghosts are 'the unburied. And liars'; ${ }^{94}$ and so, within the play's logic, all those wronged in Irish history and its wrong-doers - return in defiance of death's silence. The invisible become palpable, mirroring how the stories of the Disappeared have become politically visible in response to what Peake and Lynch identify as 'undulations of the political landscape.95 As Ed Moloney points out, Jean McConville's disappearance 'came back to haunt Sinn Fein during the height of the peace process in the mid-1990s'; in 2014, Gerry Adams was arrested in relation to her death, although he subsequently received no charges. ${ }^{96}$ Both onstage and off, history becomes a ghostly presence, as buried injustices revive after years of silence to haunt the audience with their own voice.

\footnotetext{
89 W.B. Yeats, ed. Fairy and Folk Tales of Ireland (New York: Macmillan, 1973), p.99.

${ }^{90}$ Jez Butterworth, Jerusalem (London: Nick Hern Books, 2010) p.109.

91 Yeats, Fairy and Folk Tales, p.117.

92 Butterworth, Ferryman, p.59.

${ }^{93}$ Butterworth, Jerusalem, p.109.

${ }^{94}$ Butterworth, Ferryman, p.125.

95 Peake and Lynch, p.453.

${ }^{96}$ Moloney, p.124, emphasis added; 'No charges against Gerry Adams but Jean McConville's family vow to seek justice’ Belfast Telegraph, (29 September 2015) < https://www.belfasttelegraph.co.uk/news/republic-ofireland/no-charges-against-gerry-adams-but-jean-mcconvilles-family-vow-to-seek-justice-31567533.html > [accessed 1 February 2018].
} 


\section{Closure and disclosure}

The Ferryman ends with political and supernatural forces enclosing the Carney's pastoral idyll. Arthur Miller argues that tragedy 'requires the finest appreciation by the writer of cause and effect', ${ }^{97}$ and The Ferryman uncovers how this cramping of physical, political, and ethical space stems from the land's legacy. As Aunt Pat proffers, 'Who are we in a war with these past four hundred years?"98

This form of closure, 'that which encloses, shuts in, or confines; a fence, wall, barrier, case, cover, setting, etc. ${ }^{99}$ is a force that both represses and radicalises. In Act Two, the audience hears of Quinn's internment 'back in the cage, ${ }^{100}$ a personal history which he hides. This buried memory embodies both the physical and the verbal forms of closure that ghost The Ferryman, driving its characters to radical action. Internment was, in 1916 and 1972, a catalyst for violence and a Republican hothouse. ${ }^{101}$ It is emblematic of the Troubles, a conflict defined by 'a fundamental polarization within such a tiny space'. ${ }^{102}$

The Ferryman appeals for disclosure over closure. Disclosure is 'the action or fact of disclosing or revealing new or secret information; the action of making something openly known. ${ }^{, 103}$ In his poem, 'Mahogany Gaspipes', Bernard O’Donoghue remarks on how Irish voices are sometimes lost, or distorted, as they cross the Irish sea:

They didn't seem to hear what we were saying across the water: probably the wind was in the wrong direction and blew away our voices. ${ }^{104}$

\footnotetext{
97 Miller, 'Tragedy', p.63.

98 Butterworth, Ferryman, p.32.

99 'closure, n.' OED Online (Oxford: Oxford University Press, June 2018)

$<$ www.oed.com/view/Entry/34641> [accessed 8 February 2018].

100 Butterworth, Ferryman, p.80.

101 R.F. Foster, Modern Ireland: 1600-1972, (London: Penguin, 1989), p.590.

102 Ibid., p.583.

103 'disclosure, n’. OED Online (Oxford: Oxford University Press, June 2018)

$<$ www.oed.com/view/Entry/53779> [accessed 2 July 2018].

104 Bernard O’Donoghue, 'Mahogany Gaspipes' in The Seasons of Cullen Church (London: Faber, 2016), p.5.
} 
Though Donoghue speaks to an Irish experience, his message could also be applied to suppressed Northern Irish narratives. By unearthing stories silenced within families, communities, and at the highest political level, The Ferryman has re-opened a dialogue on the Disappeared and added to the gathering excavation of secrets buried within Northern Ireland's recent history. Sandra Peake believes that The Ferryman has 'brought the issue of the Disappeared [...] back into the public area again, in terms of in England'. ${ }^{105}$ The play has ferried between the isles to tell a story still relatively unknown across the waters.

The play's act of revenge humanises the dehumanising, while displaying the futility - and logic - of violence. Revenge is a fitting mode for sectarianism, as it stages how, through the act or attempt of killing, 'the sins of the fathers are visited upon the sons'. ${ }^{106}$ Revenge becomes a chthonic cycle which is inherited and perpetuated by Quinn and Oisin. Hope must exist within tragedy, to prove, as Miller puts it, that humans are 'capable of flowering on this earth'. ${ }^{107}$ The Ferryman's ambiguous ending enacts the Carneys' entrapment by near certain death, while also dramatising the ascent of the Troubles' buried ghosts into the public consciousness. Within Northern Irish politics, the rise of Mary Lou McDonald, who succeeded Gerry Adams as President of Sinn Fein this year, promises to open a new chapter in Republican politics - she has, in her words, brought 'her own shoes to fill'. ${ }^{108}$

To conclude on whether Butterworth does justice to the Troubles requires further space than here allows. By traveling outside Northern Ireland, what The Ferryman offers is a personal appeal for dialogue beyond borders. As it tours on Broadway, and as national

\footnotetext{
105 Peake.

${ }^{106}$ Kerrigan, p.8.

107 Arthur Miller, 'The Nature of Tragedy' in The Collected Essays of Arthur Miller ed. by Matthew Roudane (London: Bloomsbury Methuen Drama, 2016), pp. 11-13, p.13.

108 'Sinn Fein's Mary Lou McDonald brought "her own shoes to fill”" BBC News, BBC, (20 January 2018) $<$ https://www.bbc.co.uk/news/av/world-europe-42758915/sinn-fein-s-mary-lou-mcdonald-brought-herown-shoes-to-fill> [accessed 8 February 2018].
} 
and global politics develop, the play will continue to ask its audiences to speak out - not to stay silent: to disclose in the face of closure, in order to put past ghosts to rest.

\section{Works Cited}

'100 Greatest Rolling Stone Songs' Rolling Stone, (15 October 2013)

$<$ https://www.rollingstone.com/music/lists/100-greatest-rolling-stones-songs-

20131015> [accessed 10 January 2018].

Bew, Paul and Gordon Gillespie, Northern Ireland: A Chronology of the Troubles 1968-1999

(Dublin: Gill \& Macmillan, 1999).

Butterworth, Jez, Jerusalem (London: Nick Hern Books, 2010).

---. The Ferryman (London: Nick Hern Books, 2017).

---. 'The Ferryman: Jez Butterworth on the Legacy of Hate', The Atlantic (5 September 2017)

$<$ https://www.theatlantic.com/entertainment/archive/2017/09/the-ferryman-jez-

butterworth-on-the-legacy-of-hate/537984/> [accessed 10 February 2018].

Butterworth, Jez and Sam Mendes, 'Jez Butterworth and Sam Mendes on The Ferryman'

Front Row, BBC Radio 4, (22 June 2017)

$<$ https://www.bbc.co.uk/programmes/b08tvjkc> [accessed 10 January 2018].

Carney, Sean, The Politics and Poetics of Contemporary English Tragedy (Toronto: University of Toronto Press, 2013).

'closure, n.' OED Online (Oxford: Oxford University Press, June 2018)

$<$ www.oed.com/view/Entry/34641> [accessed 8 February 2018].

Coates, Richard A., Patrick Hanks, and Peter McClure, 'Kearney' in The Oxford Dictionary of Family Names in Britain and Ireland. (Oxford: Oxford University Press, 2016)

< http://www.oxfordreference.com/view/10.1093/acref/9780199677764.001.0001

Lacref-9780199677764-e-21983\#> [accessed 10 January 2018].

Conn Liebler, Naomi, Shakespeare's Festive Tragedy: The Ritual Foundations of Genre (London: Routledge, 1995).

Connell, K.H., 'The Potato in Ireland', in Nationalism and Popular Protest in Ireland, ed. by

C.H.E. Philpin (Cambridge: Cambridge University Press, 1987), pp.110-125.

'disclosure, n'. OED Online (Oxford: Oxford University Press, June 2018), $<$ www.oed.com/view/Entry/53779> [accessed 2 July 2018].

Donnelly, Laura, 'Actress Laura Donnelly on how uncle's IRA murder inspired hit West End play', The Irish News (11 September 2017)

<https://www.irishnews.com/arts/2017/09/11/news/actress-laura-donnelly-onhow-uncle-s-ira-murder-inspired-hit-west-end-play-1130900/> [accessed 1 February 2018].

---. 'The Ferryman's Laura Donnelly on how her uncle's murder inspired the IRA drama.'

The Guardian, (8 August 2017)

<https://www.theguardian.com/stage/2017/aug/08/laura-donnelly-the-ferrymanjez-butterworth-paddy-considine $>$ [accessed 21 December 2017]. 
Fay, Marie-Therese, Mike Morrissey, and Marie Smyth, Northern Ireland's Troubles: The Human Costs. (London: Pluto Press, 1999).

Foster, R.F., 'Ascendancy and Union', in The Oxford History of Ireland ed. by R.F. Foster,

(Oxford: Oxford University Press, 2001), pp.134-173, p.170.

---. Modern Ireland 1600-1972, (London: Penguin, 1989).

Hanks, Patrick, Kate Hardcastle, and Flavia Hodges, 'Quinn' in A Dictionary of First Names. $2^{\text {nd }}$ ed. (Oxford: Oxford University Press, 2006)

<http://www.oxfordreference.com/view/10.1093/acref/9780198610601.001.0001 /acref-9780198610601-e-2635? rskey $=$ FyW7uB\&result $=1>$ [accessed 10 January 2018].

Heaney, Seamus, trans. Aeneid Book VI by Virgil (London: Faber, 2016).

Hickey, D.J., and J.E. Doherty, 'Kettle, Thomas M.' in A Dictionary of Irish History Since 1800 (Dublin: Gill and MacMillan, 1980), p.279.

Howard, Jean E. Shakespeare's Art of Orchestration: Stage Technique and Audience Response (Illinois: University of Illinois Press, 1984).

Johnson, D.S., and Liam Kennedy, 'The Two Economies in Ireland in the Twentieth Century' in A New History of Ireland VII: Ireland, 1921-84, ed. By J.R. Hill. (Oxford: Oxford University Press, 2003), pp. 452-472.

Kerrigan, John, Revenge Tragedy: Aeschylus to Armageddon (Oxford: Oxford University Press, 2000).

Loughlin, James, The Ulster Question since 1945, $2^{\text {nd }}$ ed., (Basingstoke: Palgrave Macmillan, 2004).

Lyons, F.S, 'The Rising and After' in A New History of Ireland VI: Ireland under the Union 1870-1921, ed. by W.E. Vaughan (Oxford: Oxford University Press, 2012), pp. 207223.

Macauley, Conor, 'County Armagh apple growers: Harvest worth $£ 20 \mathrm{~m}$ a year', BBC News, BBC (29 September 2015) < https://www.bbc.co.uk/news/uk-northernireland-34381677> [accessed 18 February 2018.]

Mendes, Sam, 'In Conversation with Sam Mendes', programme for Jez Butterworth's The Ferryman at the Gielgud Theatre (London: Dewynters, 2017), pp.35-36.

Moloney, Ed, A Secret History of the IRA (London: Penguin, 2002).

MacIntyre, Darragh, Personal Interview, 8 January 2018.

'No charges against Gerry Adams but Jean McConville's family vow to seek justice', Belfast Telegraph (29 September 2015)

$<$ https://www.belfasttelegraph.co.uk/news/republic-of-ireland/no-chargesagainst-gerry-adams-but-jean-mcconvilles-family-vow-to-seek-justice31567533.html > [accessed 1 February 2018].

Mercier, Vivian, 'Literature in English, 1891-1921' in A New History of Ireland VI: Ireland under the Union 1870-1921, ed. by W.E. Vaughan, (Oxford: Oxford University Press, 2012), pp.357-384.

Miller, Arthur, 'The Nature of Tragedy' in The Collected Essays of Arthur Miller, ed. by Matthew Roudane (London: Bloomsbury Methuen Drama, 2016), pp. 11-13.

---. 'Tragedy and the Common Man', Jewish Quarterly, 62:4 (2015), 62-63.

O’Donoghue, Bernard, 'Mahogany Gaspipes' in The Seasons of Cullen Church (London: Faber, 2016). 
O'Hagan, Sean, 'Critics loved The Ferryman. But I'm from Northern Ireland, and it doesn't ring true' The Guardian, (16 July 2017)

<https://www.theguardian.com/commentisfree/2017/jul/16/jez-butterworth-theferryman-irish-stereotypes-sam-mendes $>$ [accessed 29 June 2018].

O'Halpin, Eunan, 'Problematic Killing in the Irish War of Independence: the Killing of Spies and Informers' in Death and Dying in Ireland, Britain and Europe: Historical Perspectives, ed. by James Kelly and Mary Ann Lyons (Sallins: Irish Academic Press, 2013), pp.317-348.

Paterson, Stewart, 'Married Polish couple want YOU to fund their Brexit! Family plead for $£, 10,000$ on fundraising site to get them back to Krakow... after EU vote left them 'stressed and insecure' in UK', Daily Mail Online (12 September 2017) < http://www.dailymail.co.uk/news/article-4875672/Married-Polish-couple-wantfund-Brexit.html> [accessed 18 January 2018].

Patterson, Henry, Ireland's Violent Frontier: The Border and Anglo-Irish Relations During the Troubles, (Basingstoke: Palgrave Macmillan, 2013).

Peake, Sandra, Personal Interview, 18 January 2018.

Peake, Sandra and Orla Lynch, 'Victims of Irish Republican Paramilitary Violence - The Case of "The Disappeared"', Terrorism and Political Violence, 28:3 (2016), 452-472.

Poole, Adrian, Tragedy: A Very Short Introduction (Oxford: Oxford University Press, 2005).

Rabey, David Ian, The Theatre and Films of Jez. Butterworth (London: Bloomsbury, 2015).

'Real Lives 1985.' History of the BBC, BBC

$<$ http://www.bbc.co.uk/historyofthebbc/research/culture/bbc-and-gov/reallives $>$ [accessed 1 February 2018].

Real Lives: At the Edge of the Union (television programme) (Londonderry: BBC One Television, October 1985).

Shakespeare, William, Hamlet, ed. G.R. Hibbard (Oxford: Oxford University Press, 1998).

'Sinn Fein's Mary Lou McDonald brought "her own shoes to fill”" BBC News, BBC (20

January 2018) < https://www.bbc.co.uk/news/av/world-europe-42758915/sinnfein-s-mary-lou-mcdonald-brought-her-own-shoes-to-fill $>$ [accessed 8 February 2018].

Steinbeck, John, Of Mice and Men (New York: Random House, 1974).

'Street Fighting Man' in Beggars Banquet (London: Decca, 1968).

Thatcher, Margaret, 'Press Conference ending visit to Saudi Arabia (IRA hunger strikes)', Margaret Thatcher Foundation (21 April 1981)

$<$ https://www.margaretthatcher.org/document/104501> [accessed 1 February 2018].

The Disappeared (television programme), BBC4, 5 November 2013,

$<$ https://learningonscreen.ac.uk/ondemand/index.php/prog/05F71CCC $>$

[Accessed 2 July 2018].

The Ferryman (performance) by Jez Butterworth, dir. Sam Mendes, perf. Paddy Considine and Laura Donnelly, Gielgud Theatre, London, 2017.

---. Royal Court Theatre, London, 2017.

Tonge, Jonathan, 'The Impact of Withdrawal from the European Union upon Northern Ireland' The Political Quarterly, 87: 3 (2016), 339-342. 
Trevelyan, Raleigh, Sir Walter Raleigh (London: Penguin, 2002).

Virgil, The Aeneid, trans. by Robert Fagles (London: Penguin, 2010).

WAVE, The Disappeared of Northern Ireland's 'Troubles' (Belfast: WAVE Trauma Centre, 2012).

Wolffe, John, 'The Mutations of Martyrdom in Britain and Ireland, c. 1850-2005.' in Death and Dying in Ireland, Britain and Europe: Historical Perspectives, ed. by James Kelly and Mary Ann Lyons. (Sallins: Irish Academic Press, 2013), pp. 349-368.

Yeats, W.B., ed. Fairy and Folk Tales of Ireland (New York: Macmillan, 1973).

---.'The Stolen Child.' in Yeats's Poems, ed. A Norman Jeffares (London: Macmillan, 1989), p.53-54. 